\title{
Pharmacokinetics, clearance, and biosafety of polyethylene glycol-coated hollow gold nanospheres
}

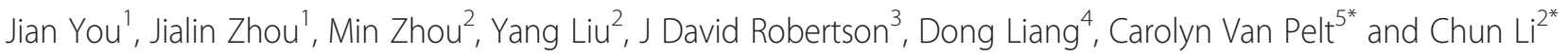

\begin{abstract}
Objective: Gold nanoparticles have attracted enormous interest as potential theranostic agents. However, little is known about the long-term elimination and systemic toxicity of gold nanoparticles in the literature. Hollow gold nanospheres (HAuNS) is a class of photothermal conducting agent that have shown promises in photoacoustic imaging, photothermal ablation therapy, and drug delivery. It's very necessary to make clear the biosafety of HAuNS for its further application.
\end{abstract}

Methods: We investigated the cytotoxicity, complement activation, and platelet aggregation of polyethylene glycol (PEG)-coated HAuNS (PEG-HAuNS, average diameter of $63 \mathrm{~nm}$ ) in vitro and their pharmacokinetics, biodistribution, organ elimination, hematology, clinical chemistry, acute toxicity, and chronic toxicity in mice.

Results: PEG-HAuNS did not induce detectable activation of the complement system and did not induce detectable platelet aggregation. The blood half-life of PEG-HAuNS in mice was $8.19 \pm 1.4 \mathrm{hr}$. The single effective dose of PEG-HAuNS in photothermal ablation therapy was determined to be $12.5 \mathrm{mg} / \mathrm{kg}$. PEG-HAuNS caused no adverse effects after 10 daily intravenous injections over a 2-week period at a dose of $12.5 \mathrm{mg} / \mathrm{kg}$ per injection (accumulated dose: $125 \mathrm{mg} / \mathrm{kg}$ ). Quantitative analysis of the muscle, liver, spleen, and kidney revealed that the levels of Au decreased $45.2 \%, 28.6 \%$, $41.7 \%$, and $40.8 \%$, respectively, from day 14 to day 90 after the first intravenous injection, indicating that PEG-HAuNS was slowly cleared from these organs in mice.

Conclusion: Our data support the use of PEG-HAuNS as a promising photothermal conducting agent.

Keywords: Hollow gold nanospheres, Toxicity, Photothermal ablation therapy

\section{Background}

Nanoparticles have great potential for biomedical application, not only to deliver pharmaceutics but also to be used as novel diagnostic and therapeutic agents [1,2]. The difference in the toxicity profiles of bulk materials and their corresponding nanoparticles owing to the tiny physical dimensions of nanoparticles has been widely recognized [3,4]. For example, carbon black is nontoxic; however, carbon nanotubes and fullerene are highly toxic when inhaled into the lung $[5,6]$. Similarly, the enhanced toxicity of titanium oxide nanoparticles has been

\footnotetext{
*Correspondence: cvpelt@comcast.net; cli@mdanderson.org

${ }^{5}$ Department of Veterinary Medicine and Surgery, The University of Texas MD Anderson Cancer Center, Houston 77030, TX, USA

${ }^{2}$ Department of Cancer Systems Imaging, Unit 59, The University of Texas

MD Anderson Cancer Center, Houston, TX 77030, USA

Full list of author information is available at the end of the article
}

reported $[7,8]$, and titanium oxide nanoparticles have been shown to induce oxidative stress in bacteria [9].

Gold nanoparticles (AuNPs) show several features that make them well suited for biomedical applications, including straightforward synthesis, stability, and the ability to selectively incorporate recognition molecules such as peptides or proteins [10]. AuNPs have been used as Raman sensors [11], photocatalysts [12], photoelectrochemical materials [13], photothermal conducting agents [14], biosensors [15], and carriers for the delivery of drugs and genes [16-18]. Although AuNPs are thought to be nontoxic [19-21], there are reports that document their toxicity, which has been shown to depend on the physical dimensions, surface chemistry, and shape of the AuNPs [22-26]. 
Hollow gold nanospheres (HAuNS) are a novel class of AuNPs composed of a thin Au shell with a hollow interior. Unlike solid AuNPs, HAuNS have plasmon absorption in the near-infrared (NIR) region and display strong photothermal conducting properties suitable for photothermal ablation therapy. HAuNS' unique combination of small size (30-50 $\mathrm{nm}$ in diameter) and a strong, tunable absorption band (520-950 nm) suggests that HAuNS are a promising mediator for a variety of biomedical applications, including imaging and cancer therapy [27-30]. A few studies have explored the potential utility of HAuNS as a novel delivery vehicle to shuttle biomolecules [31,32] or to trigger drug release under NIR light irradiation [33-35]. To date, there has been no detailed study on the toxicity of HAuNS. Herein, we carried out a biosafety evaluation of polyethylene glycol (PEG, molecular weight of 5000)-coated HAuNS (PEGHAuNS), including in vitro blood compatibility and in vivo acute and chronic toxicity assessment. We determined the effective therapeutic dose in xenograft models of human ovarian cancer and used the data to guide dose selection for systemic toxicity study.

\section{Results and discussion}

Synthesis and characterization of HAuNS and PEG-HAuNS HAuNS was readily coated with methoxy-PEG-sulfhydryl (molecular weight, 5,000). The absorption spectra showed that the plasma resonance peak for PEG-HAuNS was tuned to the NIR region $(\sim 800 \mathrm{~nm})$ (Figure 1A). The homogeneity of HAuNS is demonstrated in Figures 1B and $C$, which show representative scanning electron micrograph and low-resolution TEM images of HAuNS. The narrow size distribution of the HAuNS resulted from the narrow size distribution of the cobalt seed nanoparticles from which the HAuNS were grown. The high-resolution TEM of an individual HAuNS, shown in Figure 1D, illustrates the thin Au shell with hollow interior. TEM reviewed an average size of $43.1 \pm 5.4 \mathrm{~nm}$ (Figure 1). Dynamic light scattering revealed an average HAuNS diameter of $43.6 \mathrm{~nm}$, and average polydispersity of 0.006 . PEGylation led to a significant increase in the size of PEG-HAuNS, which had an average diameter of $62.7 \mathrm{~nm}$ and polydispersity of 0.068 . However, compared with HAuNS, PEG-HAuNS had significantly increased colloidal stability: no aggregation was observed when PEG-HAuNS were stored in water at room temperature over a period of 6 months. PEG modification did not affect the extinction spectrum of HAuNS. The physicochemical properties of HAuNS and PEG-HAuNS are summarized in Table 1.

\section{Cytotoxicity}

The cytotoxicity of PEG-HAuNS against both LLC-PK1 and HepG2 cells increased with increased incubation time (Additional file 1: Figure S1). PEG-HAuNS was more toxic to kidney cells than to liver cells (HepG2): the $\mathrm{IC}_{50}$ values of PEG-HAuNS after $48 \mathrm{~h}$ of incubation in LLCPK1 and HepG2 cells were $0.22 \mathrm{mg} / \mathrm{mL}$ and $>1 \mathrm{mg} / \mathrm{mL}$, respectively.

On the basis of cytotoxicity assay, gold nanoparticles have been found to be "non-toxic" or "toxic", depending on the physicochemical characteristics (surface charge,
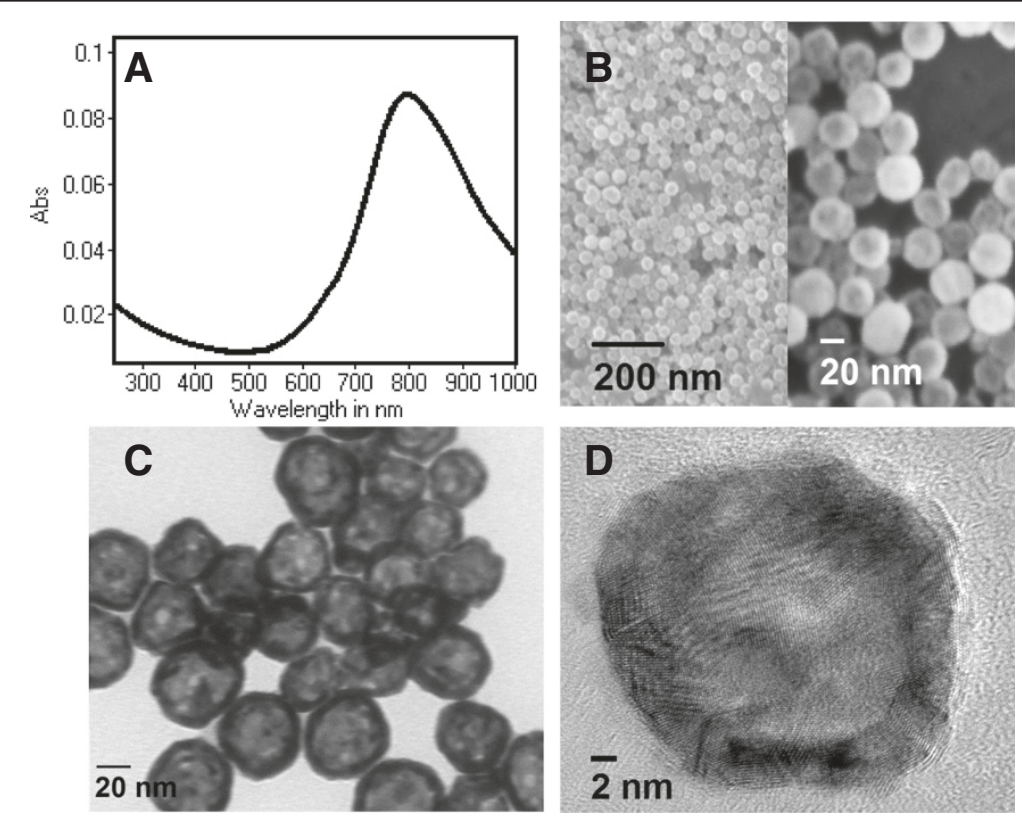

Figure 1 Characterization of HAuNS. A: Absorption spectra of HAuNS. B: Scanning electron micrograph images of HAuNS. C and D: Low- and high-resolution TEM images of HAuNS. 
Table 1 Physicochemical properties of HAuNS and PEG-HAuNS

\begin{tabular}{lll}
\hline & HAuNS & PEG-HAuNS \\
\hline Concentration $(\mathrm{mg} / \mathrm{mL})$ & $2.5 \times 10^{-3}$ & $2.5 \times 10^{-3}$ \\
Concentration (particles $/ \mathrm{mL})$ & $6.25 \times 10^{9}$ & $6.25 \times 10^{9}$ \\
Mean diameter $^{\mathrm{a}}(\mathrm{nm})$ & $43.6 \pm 0.4$ & $62.7 \pm 0.7$ \\
Polydispersity $^{\mathrm{a}}$ & $0.006 \pm 0.001$ & $0.068 \pm 0.005$ \\
Zeta potential $(\mathrm{mA})^{\text {Plasma resonance peak }(\mathrm{nm})}$ & $-23 \pm 0.8$ & $-15 \pm 0.6$ \\
Optical density $^{\mathrm{b}}$ & 802 & 801 \\
\hline
\end{tabular}

${ }^{a}$ Data are presented as mean \pm standard deviation $(n=3)$, measured by dynamic light scattering. ${ }^{\mathrm{b}}$ Optical density measured at $800 \mathrm{~nm}$.

size, and surface chemistry) of nanoparticles [26]. A direct comparison of our results with those reported in the literature would not be possible because of differences in nanoparticle characteristics and cell lines used in these studies. Nevertheless, Patra el al. [36] found that gold nanoparticles of $33 \mathrm{~nm}$ in diameter, which was only slightly smaller than our HAuNS, were not toxic to Hep2G and BHK21 (baby hamster kidney) cells. In our cytotoxicity study, concentrations of $0.22 \mathrm{mg} / \mathrm{mL}$ and $>1 \mathrm{mg} / \mathrm{mL}$ for LLC-PK1 and Hep2G cells respectively were quite high. At such concentrations, absorption at $495 \mathrm{~nm}$ by residual nanoparticles may affect MTT assay results as suggested by Alkilany et al. [26]. Because we have observed that the decrease in optical density as a function of particle dose depended on incubation time, suggesting that the effect of residual nanoparticles on the MTT assay was not significant.

\section{Complement activation and platelet aggregation}

To examine potential effects of PEG-HAuNS on the complement activation cascade, we assessed the degree of complement activation in an in vitro assay in human plasma aliquots pretreated with nanoparticles. PEG-HAuNS did not induce detectable activation of the complement system in a C3-specific qualitative assay (Figure 2A). Furthermore, PEG-HAuNS under the tested concentrations did not induce any detectable platelet aggregation (Figure 2B) and did not interfere with collagen-induced platelet aggregation (Figure 2C).

\section{Pharmacokinetics and biodistribution}

Figure 3A shows the mean blood level profile of ${ }^{64} \mathrm{Cu}$ labeled PEG-HAuNS. Terminal biological half-life, apparent volume of distribution, total body clearance, mean residence time, and total area under the blood concentration were $8.19 \pm 1.4 \mathrm{hr}, 2.78 \pm 0.63 \mathrm{~mL}, 0.235 \pm$ $0.03 \mathrm{~mL} / \mathrm{hr}, \quad 12.3 \pm 2.2 \mathrm{hr}$, and $434 \pm 61 \% \mathrm{ID} \cdot \mathrm{hr} / \mathrm{mL}$, respectively. Figure $3 \mathrm{~B}$ shows the biodistribution of PEG-HAuNS in Hey tumor-bearing mice at $24 \mathrm{~h}$ after intravenous injection. Most nanoparticles were taken up by the liver $(11.8 \pm 1.95 \% \mathrm{ID} / \mathrm{g})$ and spleen $(8.51 \pm 1.67 \% \mathrm{ID} / \mathrm{g})$. Because blood was not perfused prior to measurements in

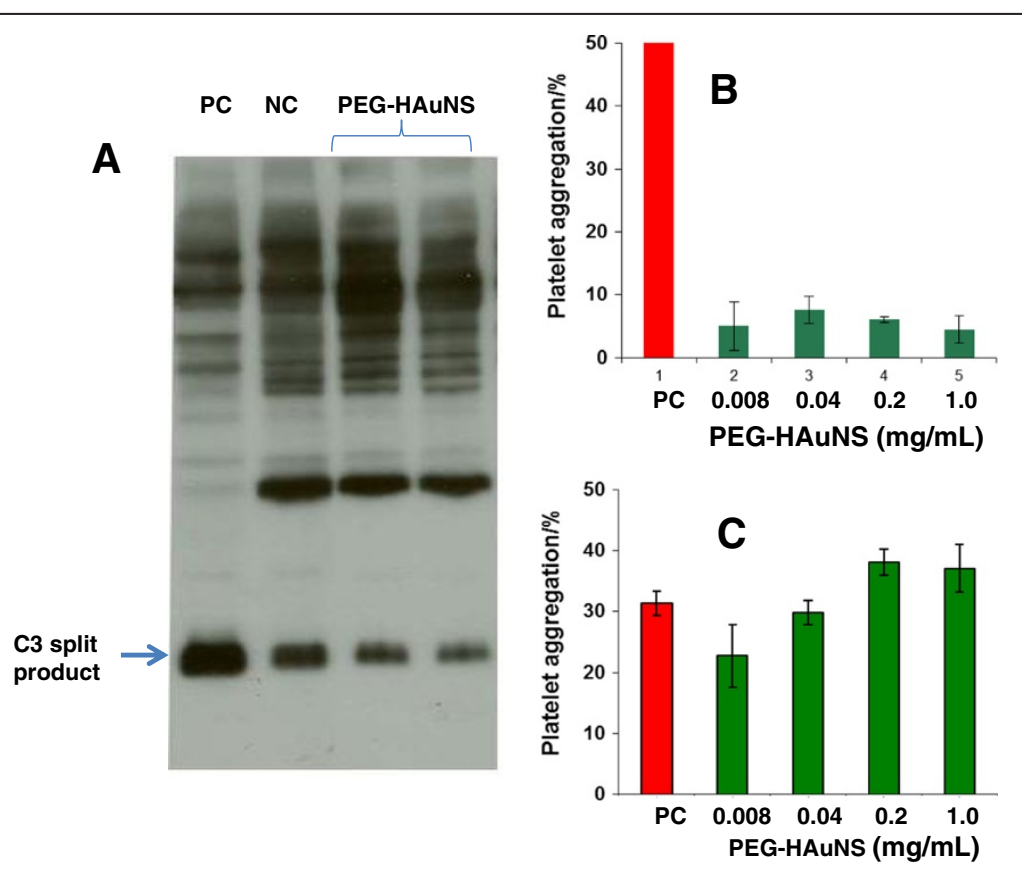

Figure 2 In vitro complement activation and platelet aggregation assays. A: Complement activation assay of PEG-HAuNS (1 mg/mL). The nanoparticles did not result in the detectable activation of a complement system. PC, positive control (cobra venom), NC, negative control (PBS). B: Platelet aggregation in the presence of PEG-HAUNS. PEG-HAUNS under tested concentrations did not induce platelet aggregation. C: PEG-HAUNS under tested concentrations did not interfere with collagen-induced platelet aggregation. PC, positive control (collagen). 


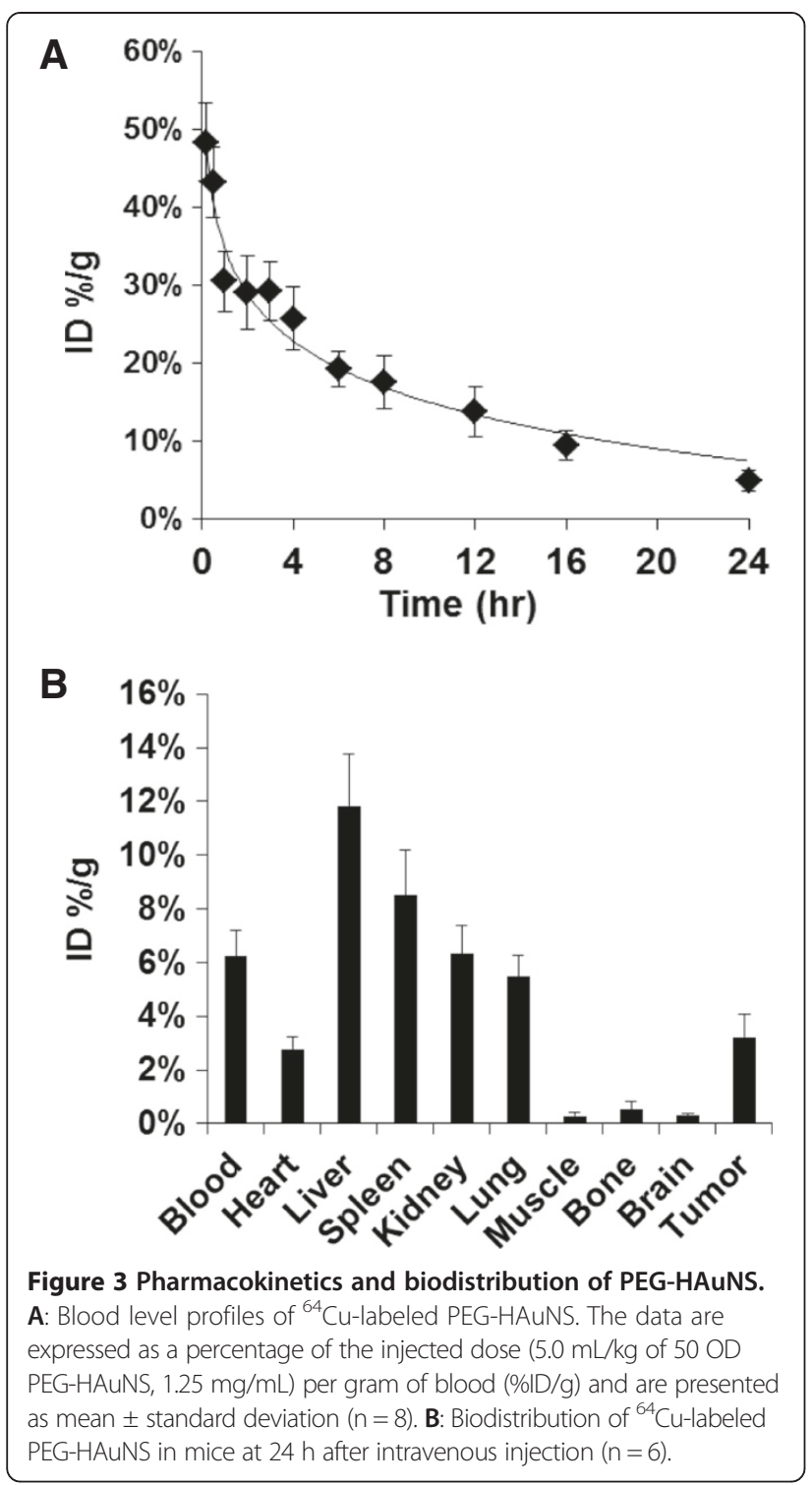

our study, the uptake values in the liver and spleen may be overestimated owing to the contribution of PEGHAuNS in the blood in these organs. A significant amount of PEG-HAuNS also accumulated in the tumors $(3.22 \pm 0.86 \% \mathrm{ID} / \mathrm{g})$, which could be attributed to the enhanced permeability and retention effect.

Tissue distribution of PEGylated gold nanoparticles have been reported by several groups. A direct comparison of our results with those reported in the literature is difficult because particle characteristics (size, surface chemistry, charge etc.) of these gold nanoparticles are very different. Lankveld et al. [37] found that spleen was the major organ of particle deposition in rats for PEGylated gold nanorods $(55.3 \times 18.5 \mathrm{~nm})$. Similar finding was reported by Akiyama et al. [38] using PEGylated nanorods of $55 \times 9 \mathrm{~nm}$ in average size in mice. Interestingly, a PEGylated gold nanorod preparation with slightly different size
$(65 \times 11 \mathrm{~nm})$ showed mostly liver uptake and minimal spleen uptake $24 \mathrm{~h}$ after intravenous injection in mice [39]. We have found a size-depend distribution pattern for spherical gold nanoparticles coated with PEG. Thus, PEGylated gold nanoparticles of smaller size (20-nm in diameter) had longer blood half-life and lower uptake in the liver and spleen than those of larger size $(80-\mathrm{nm}$ in diameter) [40]. In agreement with the current findings, PEGylated gold nanoparticles were largely distributed to the liver and the spleen [40].

\section{Antitumor activity}

To facilitate selection of a more realistic dosing schedule for assessment of toxicity of PEG-HAuNS, we first determined the effective dose of PEG-HAuNS in NIR laser-induced photothermal ablation therapy in a human ovarian tumor model (Figure 4). Results from Hey tumor-bearing nude mice showed a dose-response to PEG-HAuNS at a laser output power of $2.5 \mathrm{~W} / \mathrm{cm}^{2}$ for $3 \mathrm{~min}$ of continuous illumination. At a single dose of $5.0 \mathrm{~mL} / \mathrm{kg}$ of $100 \mathrm{OD}(12.5 \mathrm{mg} / \mathrm{kg})$, PEG-HAuNS displayed the greatest antitumor activity (Figure $4 \mathrm{~A}$ and $\mathrm{B}$ ). All of the tumors in this group shrank to small lumps, which were barely palpable (Figure $4 \mathrm{C}$ ). Average body weight of the mice in the 50-OD and 100-OD dosing groups decreased after NIR laser illumination, with about $5 \%$ body weight loss on day 4 after the illumination. No change in body weight for the mice in both the saline and 25-OD dosing groups was observed during the same period (Figure 4D). The body weight of all treated groups started to recover 4 days after laser illumination.

Additional file 1: Figure S2 shows the A2780 tumorgrowth curves after intravenous injection of saline or PEGHAuNS (single dose, $5.0 \mathrm{~mL} / \mathrm{kg}$ of $50 \mathrm{OD}, 6.25 \mathrm{mg} / \mathrm{kg}$ ), followed by NIR laser treatment $\left(2.5 \mathrm{~W} / \mathrm{cm}^{2}\right.$ for $\left.3 \mathrm{~min}\right)$ at $24 \mathrm{~h}$ after injection. PEG-HAuNS followed by NIR laser treatment significantly inhibited the growth of the tumors. The average tumor weight in this group on day 21 was $0.1 \pm 0.02 \mathrm{~g}$, which was significantly smaller than that of the saline and laser-treated control groups $(2.0 \pm$ $0.4 \mathrm{~g})(p<0.001)$. Thus, a single dose of PEG-HAuNS ranging from $6.25 \mathrm{mg} / \mathrm{kg}$ to $12.5 \mathrm{mg} / \mathrm{kg}$ were effective in mediating photothermal ablation therapy.

\section{Acute and chronic toxicity}

The available literature on in vitro and in vivo toxicity of AuNPs showed contradicting findings, primarily because in vivo behaviors of AuNPs are dependent on their physicochemical characteristics [26]. Little is known about AuNPs' elimination from major organs and their longterm biosafety after intravenous injection [26]. In this context, there is a real need to investigate the in vivo toxicity of gold-based nanoparticles intended for therapeutic use, in particular after long-term exposure (>60 days). On the 


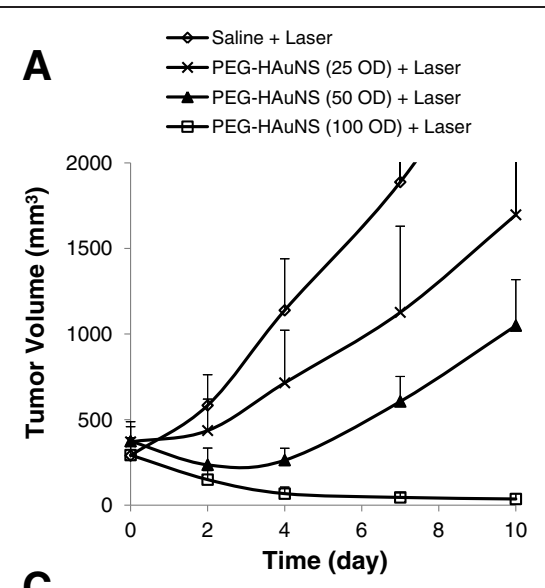

C

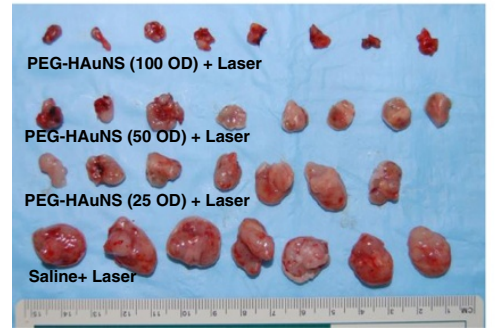

B
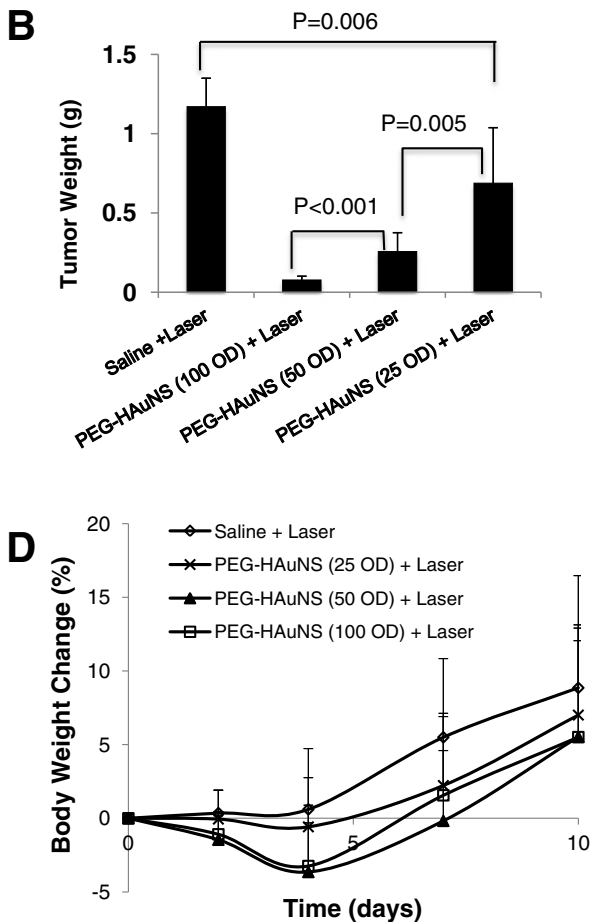

Figure 4 Antitumor activity of PEG-HAuNS against Hey tumors in nude mice. A: Hey tumor growth curves in mice treated with saline $(n=7)$, and PEG-HAuNS at doses ranging from $5 \mathrm{~mL} / \mathrm{kg}$ of $25 \mathrm{OD}(\mathrm{n}=7,3.125 \mathrm{mg} / \mathrm{kg}), 50 \mathrm{OD}(\mathrm{n}=8,6.25 \mathrm{mg} / \mathrm{kg})$, and $100 \mathrm{OD}(\mathrm{n}=8,12.5 \mathrm{mg} / \mathrm{kg})$. All tumors received NIR laser illumination from the tumor's surface $\left(2.5 \mathrm{~W} / \mathrm{cm}^{2}\right.$, for $\left.3 \mathrm{~min}\right)$ at $24 \mathrm{~h}$ after a single dose nanoparticle injection. B: Average weight of tumors in saline- and PEG-HAuNS-treated groups on day 10 after NIR laser illumination. C: Photographs of excised tumors on day 10 after NIR laser illumination. D: Percentage change in mean body weight.

basis of the therapeutic studies, systemic toxicity study of PEG-HAuNS was conducted at an intravenous dose of $12.5 \mathrm{mg} / \mathrm{kg}$ per injection, for a total of 10 injections administered over a 2 week period. No clinical signs were observed during the course of the study, and all animals survived until their scheduled termination. No toxicologically important alterations in body weights and relative organ weights were observed at either time point (day 14 and day 90 after start of treatment) (See Additional file 1: Tables S1 and S2 for specific group means and calculated percent of control).

\section{Hematology}

A complete blood count and clinical chemistry parameters were performed on the cardiac blood collected at the time of necropsy for both 14-day and 90-day time points. Table 2

Table 2 Group means for both sacrifice dates and both sexes for clinical chemistry

\begin{tabular}{|c|c|c|c|c|c|c|c|c|c|}
\hline & $\begin{array}{c}\text { Parameter* } \\
\text { Unit }\end{array}$ & $\begin{array}{c}\text { Creatinine } \\
\mathrm{mg} / \mathrm{dL}\end{array}$ & $\begin{array}{c}\text { BUN } \\
\mathrm{mg} / \mathrm{dL}\end{array}$ & $\begin{array}{c}\text { AST } \\
\mathrm{mg} / \mathrm{dL}\end{array}$ & $\begin{array}{l}\text { ALT } \\
\text { IU/L }\end{array}$ & $\begin{array}{c}\text { ALK PHOS } \\
\text { IU/L }\end{array}$ & $\begin{array}{c}\text { T. Protein } \\
\text { IU/L }\end{array}$ & $\begin{array}{c}\text { Albumin } \\
\text { g/dL }\end{array}$ & $\begin{array}{c}\text { Globulin } \\
\text { g/dL }\end{array}$ \\
\hline \multirow[t]{2}{*}{14 days (Female) } & Saline & $<0.20$ & 16.1 & 443 & 259 & 128 & 4.91 & 3.63 & 1.29 \\
\hline & PEG-HAuNS & $<0.20$ & 14.3 & 515 & 316 & 136 & 5.18 & 3.59 & 1.58 \\
\hline \multirow[t]{2}{*}{90 days (Female) } & Saline & $<0.20$ & 16.9 & 273 & 130 & 92 & 5.8 & 3.61 & 2.19 \\
\hline & PEG-HAUNS & $<0.20$ & 16.4 & 406 & 202 & 84 & 5.88 & 3.75 & 2.13 \\
\hline \multirow[t]{2}{*}{14 days (Male) } & Saline & $<0.20$ & 18 & 112 & 69 & 123 & 5.63 & 3.55 & 2.07 \\
\hline & PEG-HAuNS & 0.2 & 19.8 & 322 & 256 & 123 & 5.52 & 3.33 & 2.19 \\
\hline \multirow[t]{2}{*}{90 days (Male) } & Saline & 0.22 & 20.3 & 152 & 109 & 137 & 6.62 & 3.83 & 2.79 \\
\hline & PEG-HAUNS & 0.27 & 17.6 & 591 & 395 & 204 & 6.62 & 3.76 & 2.85 \\
\hline \multirow[t]{2}{*}{ Reference ranges } & Males & $0-0.4$ & $23-38$ & $0-541$ & $0-561$ & $110-219$ & $5.1-6.2$ & $2.5-3.2$ & $2.5-3.0$ \\
\hline & Females & $0-0.4$ & $19-33$ & $0-671$ & $0-596$ & $113-223$ & $5.3-6.3$ & $2.8-3.5$ & $2.4-2.9$ \\
\hline
\end{tabular}


and Additional file 1: Tables S3 summarize the group means for each group and the laboratory reference range for 6- to 8-week-old CD-1 mice using the same instruments used in this study. Differences in the mean values of the PEG-HAuNS-treated groups are highlighted if there were alterations from their respective concurrent control group.

The only alterations in hematology (using concurrent controls) occurred in females at 14 days. The total white blood cell, absolute lymphocyte, and eosinophil counts were slightly elevated but returned to normal by the 90 day time point. These alterations were minimal and not considered toxicologically important.

\section{Clinical chemistry}

The chemistry parameters evaluated were creatinine, blood urea nitrogen, aspartate aminotransferase (AST), alanine aminotransferase (ALT), alkaline phosphatase, total protein, albumin, and globulin.

The AST and ALT group means were increased in both sexes at both day 14 and day 90 , compared to their respective controls. However, none of the groups, except the males at the 90-day treatment time point, had an increase above the reference range of the laboratory. Examination of the individual animal data for these 2 parameters indicated that mice in all the groups had samples with severely hemolyzed sera that can falsely elevate both AST and ALT. When the values for AST and ALT from animals with severe hemolysis were eliminated from computation of the group means, no increase above the reference range for this laboratory was observed. On the basis of this analysis, this alteration in these 2 parameters appeared spurious, and related to sample quality, i.e., hemolysis. This interpretation was supported by normal values for the other clinical chemistry parameters measured to evaluate the liver, i.e., total protein, albumin, and globulin levels. This interpretation was also supported by the relative organ weight data for the liver. Correlation with the histopathology data showed very minimal focal necrosis and minimal deposit of pigment in occasional hepatocytes that could potentially increase both ALT and AST.

\section{Gross pathology}

PEG-HAuNS-related gross pathological findings observed in the PEG-HAuNS-treated group on day 14 were limited to liver lesions. This lesion was recorded as a discoloration of the liver in all test animals from both sexes. This discoloration correlates with pigment observed in the Kupffer cells of the liver on microscopic examination. No gross lesions were observed in any of the animals at day 90 .

\section{Microscopic pathology}

Summary incidences and average group grades for all microscopic observations at both day 14 and day 90 were presented in Additional file 1: Tables S4. The major microscopic observation in the PEG-HAuNS-treated groups was deposition of a brown-black pigment in the liver, spleen, lungs, heart, adrenal cortex, and injection site. The largest amounts of pigment were observed in the liver and spleen. All treated mice had deposition of pigment in the liver (24/24) and 16/24 treated mice had pigment deposited in the spleen. Pigment was more prevalent at 14 days and had diminished by 90 days in these 2 organs. The incidence of this pigment in the other organs was as follows: lung (2/24), heart (7/24), adrenal cortex $(3 / 24)$, and injection site at the tail vein $(3 / 24)$. It was minimal in quantity, frequently occurred in perivascular areas in these organs, and generally was not associated with inflammatory or degenerative changes. It is not clear why PEG-HAuNS stayed at perivascular areas. One possible explanation is that these nanoparticles came from blood during tissue processing because blood was not perfused at the time of euthanization and tissue harvesting. Another possibility is that some of the nanoparticles were able to penetrate endothelial lining and trapped in the perivascular area. Further studies are needed to clarify this interesting observation.

The major target organs were considered the liver and spleen, and the monocytic-macrophage system was the primary target.

Liver In both female and male mice, a dark, brownblack pigment was observed, primarily in the macrophages (Kupffer cells) of the liver and occasionally in a few hepatocytes. This pigment was present in nearly all Kupffer cells at the 14-day time point in females and males, but there was a decrease in the number of Kupffer cells affected and a slight decrease in the quantity (lesion grades) of the pigment at the 90-day time point in both females and males (Figure 5A). Special stains (Perl's iron, Schmorl's stain for lipofuscin, Periodic Acid-Schiff [PAS], and acid-fast) (Figure 5B) were done to characterize this pigment. The Schmorl's stain was positive in the liver and spleen, but the other stains to confirm lipofuscin (PAS, acid-fast) were negative, indicating the pigment was not lipofuscin. Samples of formalin-fixed liver were submitted for transmission electron microscopic study (TEM) and confirmed that the pigment observed in the Kupffer cells and some hepatocytes was electron-dense nanospheres comparable to the injected PEG-HAuNS (Figure 6A).

To further confirm liver uptake of PEG-HAuNS, samples of liver were submitted for Au quantification using neutron activation analysis (control and treated at both time points). Au was only detected in the treated samples. Although there was a general trend of decreasing concentration from day-14 to day-90 for muscle, liver, spleen, and kidney in both male $(\mathrm{n}=3)$ and female mice $(n=3)$ (Figure 6B), the differences were not statistically 


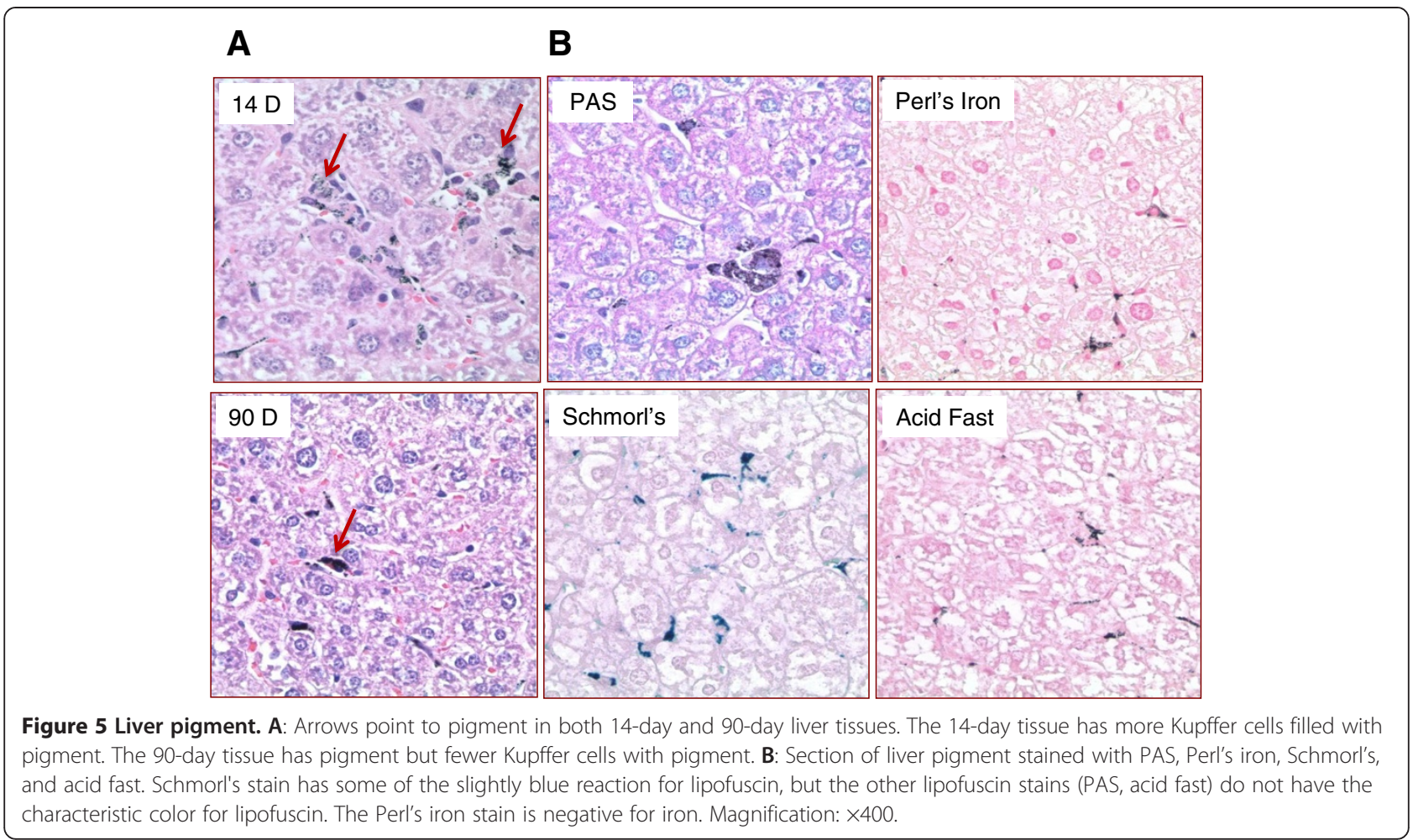

significant with the exception of spleen in female mice $(p=0.05)$. However, when data from both male and female mice are combined $(n=6)$, significant differences in tissue concentration of $\mathrm{Au}$ for all organs analyzed (muscle, liver, spleen, and kidney, with $\mathrm{p}$ values of 0.006, 0.027, 0.011, and 0.015 , respectively) were demonstrated (Figure $6 \mathrm{C}$ ). Thus, the levels of $\mathrm{Au}$ in the muscle, liver, spleen, and kidney decreased $45.2 \%, 28.6 \%, 41.7 \%$, and $40.8 \%$, respectively, from day 14 to day 90 after the first intravenous injection (Table 3). These data suggest that PEG-HAuNS could be cleared from the body, albeit at a very slow rate.

Both inflammation and necrosis were minimal in the livers. Inflammation occurred in both control and treated animals of both sexes at both time points, but there was a slightly higher incidence and minimally increased severity in the treated animals. At day 90, the incidence and severity decreased slightly in females but increased slightly in males. The severity grade was slight and not considered adverse. Focal necrosis was observed in female mice only at the 90-day time point, with an incidence of 2 (out of 6 mice) and an average grade of 1 . In male mice, focal necrosis was observed at the 14-day time point, with an incidence of 3 of 6 and a grade of 1 , but not at the 90-day time point. Since an incidence of only 1 was observed in the male controls at day 14, there was a very slight increase in focal necrosis in both females and males; however, the time of occurrence did not correlate between the sexes. Thus, this is a minimal increase over controls and not considered adverse.
In summary, the major hepatic lesion was a deposition of pigment in the macrophages of the liver (Kupffer cells). The pigment was identified as a deposition of the $\mathrm{Au}$ nanospheres by both TEM and quantitative analysis of selected formalin-fixed samples of liver from this study (Figure 6). Comparison of pigment in histopathology samples between groups and quantitative analysis for $\mathrm{Au}$ indicate that the deposited pigment was greatest at the 14-day time point and was decreasing at the 90day time point, indicating slow clearance at 90 days. Minimal hepatic lesions of inflammation and necrosis were observed, but the incidence and severity were minimal in both sexes and not considered adverse. The increase and continued presence of mononuclear inflammation in both sexes suggest these cells may be recruited macrophages for the removal of pigment, a normal biologic response that does not have adverse effects.

Spleen A dark brown-black pigment consistent with the pigment observed in the liver was observed in the macrophages of the spleen in the treated animals at both time points. At 14 days the pigment deposition was small and diffusely throughout the spleen. At 90 days, the pigment was larger but fewer aggregates distributed focally and randomly throughout the spleen (Additional file 1: Figure S3). Based on the histopathologic analysis and the Au quantification (Figure 6B), this pigment was interpreted to be the injected PEG-HAuNS. Its presence in the macrophages of the spleen is considered a normal 


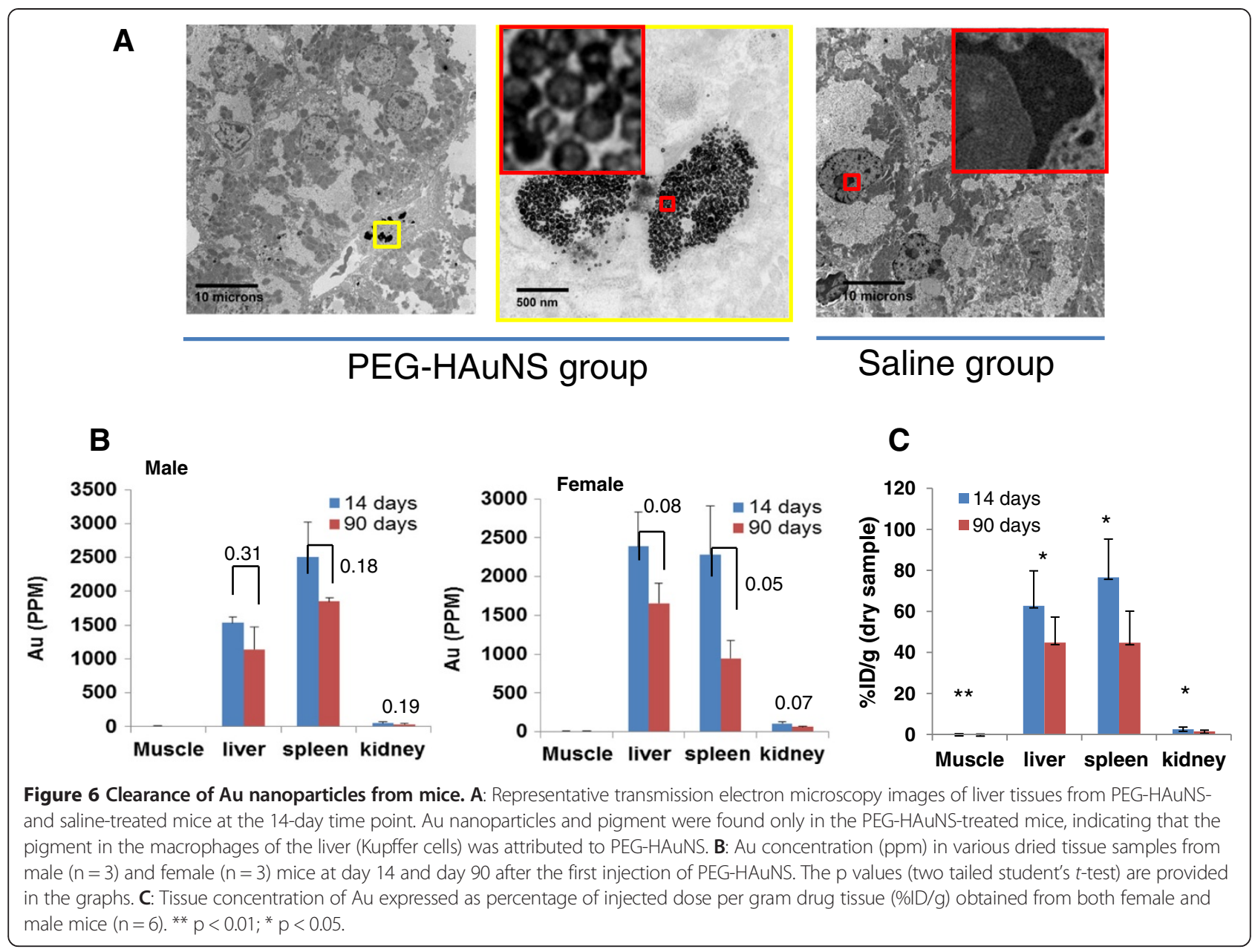

biologic response of removing foreign material and not adverse. An increase in follicular lymphoid hyperplasia and extramedullary hematopoiesis was observed in PEGHAuNS-treated animals compared to the respective controls, but the incidence and severity was minimal, considered a normal biologic response to injection of foreign material, and not adverse.

Lung Several types of inflammation were observed in the lungs; these inflammatory lesions included mononuclear (histiocytic) cells and granuloma formation. These lesions were more prevalent in the treated animals than in the controls. In the treated animals, a dark

Table 3 Percentage decrease in gold concentration in various organs for male and female mice from day 14 to day 90

\begin{tabular}{lllll}
\hline & Muscle & Liver & Spleen & Kidney \\
\hline Males $(n=3)$ & 44.6 & 25.2 & 26.2 & 38.8 \\
Females $(n=3)$ & 45.7 & 30.8 & 58.6 & 41.8 \\
Males \& females $(n=6)$ & 45.2 & 28.6 & 41.7 & 40.8 \\
\hline
\end{tabular}

brown-black pigment was found in a few of the inflammatory lesions (Figure 7A). In the female mice, the incidence of the lesions was higher at the 14-day time point when considering all lesions and decreased at the 90-day time point, indicating recovery. In the male mice, the lesions were fewer and less severe but persisted to the 90day time point. Special stains (PAS, Perl's iron, Schmorl's stain for lipofuscin, acid fast) did not identify any foreign material in the granulomas. All lesions except 1 were grade 1 , indicating minimal involvement. On the basis of this minimal involvement, the lesions were not considered adverse. While some of these lesions may or may not be related to treatment, they are minimal severity, and low incidence and not considered to have any significant impact on the health of the animals with them.

Heart Murine cardiomyopathy occurs in mice and the morphologic changes include myocyte degeneration/necrosis, an increase in the amount of interstitial fibrous connective tissue, and in some cases a minimal to mild infiltrate of mononuclear inflammatory cells. These agerelated cardiomyopathy have been reported in different 
A

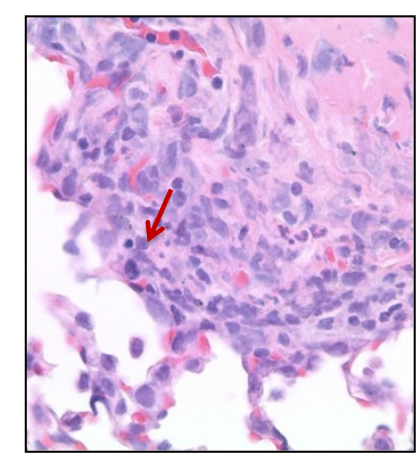

B

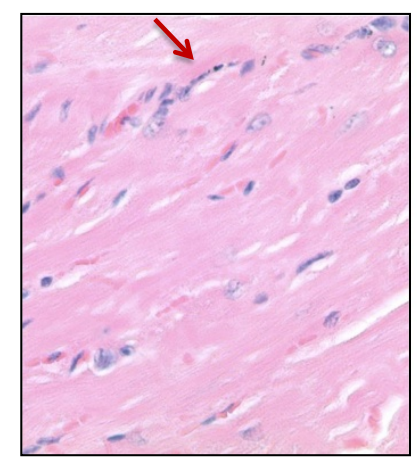

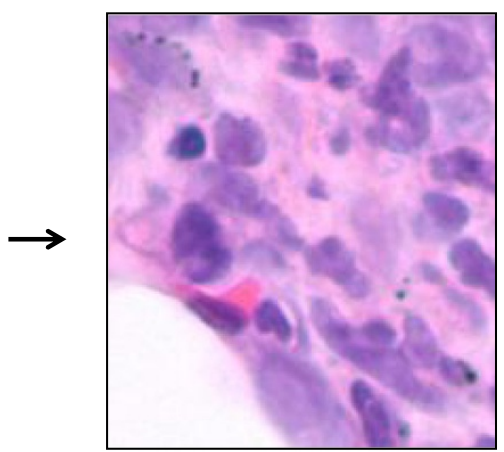

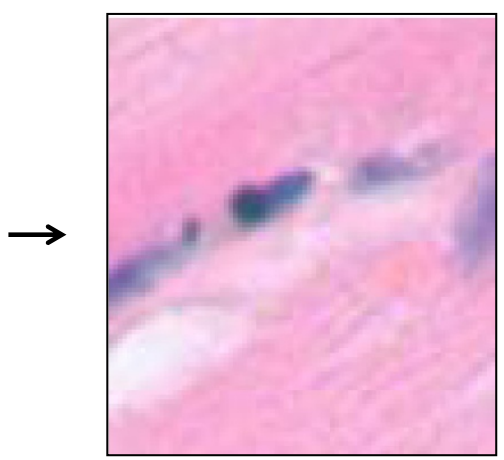

Figure 7 Pigment in lung and heart. A: The image on the left is from a 14-day-PEG-HAuNS-treated animal with peribronchiolar inflammation. Arrow points to pigment. B: Arrow points to pigment in lung tissue from a 90-day-PEG-HAuNS-treated animal. Magnification: $\times 400$.

strains of laboratory mice [41]. Inflammatory and degenerative lesions typical of spontaneous cardiomyopathy (mononuclear inflammation, myocyte degeneration, fibrosis) were observed in both the treated and control animals. However in the treated mice, these lesions were sometimes associated with very small deposits of dark brown pigment similar to that observed in other organs. This pigment was observed in 7/24 treated animals (Figure 7B) but in none of the $3 / 24$ controls that had cardiac lesions. These lesions would have been classified as spontaneous cardiomyopathy if the pigment had not been present. Since pigment is not typical of cardiomyopathy, these lesions were tabulated individually and not included under the cardiomyopathy that was used in the controls. Special stains did not identify the pigment, and all heart tissue was used in the histopathologic analysis. The pigment deposit in each case was minimal and generally a single observation in the sections of the heart examined. What cannot be explained is whether the pigment deposition was incidental to the lesions or whether its presence contributed to the development of the lesions. On the basis of the number and size of the lesions, these lesions were not considered adverse. They may or may not be related to the compound, but are not of the severity or frequency to impact the health of the animal.

Adrenal The adrenal gland in only the female mice had an increase in vacuolation of the cortex and pigment deposition in the cortex at the 14-day time point in the treated animals but not in their respective controls. By 90 days, the treated females had less vacuolation in the cortex than their respective controls, but the pigment deposition remained. Vacuolation of the adrenal cortex in the female mice occur as a result of the spontaneous regression of the X-zone of the cortex and its replacement with fat that can undergo lipogenesis (formation of lipid pigments such as lipofuscin). Special stains for lipofuscin were negative on the pigment in the adrenal cortex. Since the morphology of the pigment was similar to that observed in the heart and liver, it was presumed to be HAuNS. As observed in the heart, the pigment was minimal at best and usually only a single observation in the tissue section. Its association with a normal spontaneous process (regression of the X-zone) may be incidental. On the basis of the size of the deposits, this lesion was not considered adverse.

Injection site Deposition of a dark brown pigment similar to that observed in other tissues and identified as HAuNS occurred in the perivascular area and the wall of vessels at the injection site at the tail vein in 3/24 treated animals -2 in the 14-day group and 1 at 90 days. On the basis of the size of the lesions and frequency of tissue reaction to the pigment, it was not considered adverse.

Other organs Microscopic lesions were observed in other organs: kidney, brain, eyes (retina), spinal cord, 
sciatic nerve, intestinal tract, salivary glands, and associated lymph nodes and thyroid. These observations occurred in both the control and treated animals and did not have an increased incidence in treated animals compared to controls. These lesions are common observations in this strain of laboratory mouse and are considered incidental and spontaneous in this study.

\section{Conclusion}

In this work, we investigated the cytotoxicity, blood compatibility, pharmacokinetics, biodistribution, and systemic toxicity of PEG-HAuNS. In vitro, PEG-HAuNS did not induce detectable complement activation and platelet aggregation. Under the conditions of this study and on the basis of clinical signs, survivability, clinical pathology, and total body and relative organ weights and pathology, the administration of PEG-HAuNS was not considered adverse in female or male mice at an accumulated injection dose of $125 \mathrm{mg} / \mathrm{kg}$, which was 10-fold higher than the effective therapeutic dose. Pathologic and quantitative analysis for $\mathrm{Au}$ in formalin-fixed tissues indicated that the levels of deposited HAuNS were decreased at 90 days, but HAuNS was not completely eliminated. The primary testsubstance-related microscopic observation in this study was the deposition of pigment, primarily in the macrophages of the liver and spleen that was identified as HAuNS based on TEM and Au quantification. It is interesting to note that the increase and continued presence of mononuclear inflammation in the liver suggest these cells may be recruited macrophages for the removal of pigment, a normal biologic response that does not have adverse effects. Minute deposits of pigment (assumed to be HAuNS) were observed in the lung, heart, and adrenal cortex (only in females) and at the injection site. Importantly, quantitative analysis for $\mathrm{Au}$ in the liver, spleen, and kidney revealed that the levels of deposited PEG-HAuNS gradually decreased from day 14 to day 90 after the first injection, indicating that PEG-HAuNS was gradually cleared from the body, albeit slowly. Completely eliminating $\mathrm{Au}$ from the body may take a much longer time. Taken together, our data support the use of PEG-HAuNS as a potential photothermal conducting agent.

\section{Methods}

\section{Reagents}

Methoxy-PEG-sulfhydryl (molecular weight, 5,000) was purchased from Nektar (San Francisco, CA). (3-(4,5-Dimethylthiazol-2-yl)-2,5-diphenyltetrazolium bromide (MTT) and 4,6-diamidino-2-phenylindole (DAPI) were purchased from Sigma-Aldrich (St. Louis, MO). Trisodium citrate dehydrate (>99\%), cobalt chloride hexahydrate (99.99\%), sodium borohydride (99\%), and chloroauric acid trihydrate (American Chemical Society reagent grade) were purchased from Fisher Scientific (Pittsburgh, PA) and were used as received.
${ }^{64} \mathrm{CuCl}_{2}$ radionuclide was obtained from Washington University (St. Louis, MO).

\section{Cell culture}

Hey (human ovarian carcinoma) cells were purchased from the American Type Culture Collection (Manassas, VA). The Hey cells were maintained at $37^{\circ} \mathrm{C}$ in a humidified atmosphere containing $5 \% \mathrm{CO}_{2}$ in Dulbecco's modified Eagle's medium (DEME) and 10\% fetal bovine serum (FBS, Life Technologies, Inc., Grand Island, NY). A2780 human ovarian carcinoma cells were kindly provided by Dr. Stephen J. Williams (Fox Chase Cancer Center, Philadelphia, PA) and maintained at $37^{\circ} \mathrm{C}$ in RPMI-1640 medium containing $10 \% \mathrm{FBS}$ and insulin (0.25 units $/ \mathrm{mL})$. LLC-PK1, an epithelial porcine kidney cell line with proximal tubule properties, was obtained from the American Type Culture Collection and was grown in DEME $(1.0 \mathrm{~g} / \mathrm{L}$ glucose) supplemented with 10\% FBS, 1\% glutamine, $25 \mathrm{mmol} / \mathrm{L}$ (4-(2-hydroxyethyl)-1-piperazineethanesulfonic acid) buffer, and antibiotics. Cells were divided twice a week to ensure exponential growth and were cultured for no more than 10 passages after thawing them from stock. The human hepatocellular liver carcinoma cell line HepG2 (American Type Culture Collection) was cultured in DENE with $10 \%$ FBS and antibiotics.

\section{Synthesis and characterization of HAuNS and PEG-HAuNS}

HAuNS were synthesized according to a previously reported method [34]. Briefly, cobalt nanoparticles were first synthesized by deoxygenating deionized water containing $4.5 \mathrm{~mL}$ of $1-\mathrm{mol} / \mathrm{L}$ sodium borohydride, $2.8 \mathrm{~mL}$ of $0.1-\mathrm{mol} / \mathrm{L}$ sodium citrate, and $1.0 \mathrm{~mL}$ of $0.4-\mathrm{mol} / \mathrm{L}$ cobalt chloride. After chloroauric acid was added to the solution containing the cobalt nanoparticles, the cobalt immediately reduced the $\mathrm{Au}$ ions onto the surface of the cobalt nanoparticles, while at the same time it was oxidized to cobalt oxide. Any remaining cobalt core was further oxidized by air, resulting in the final product, HAuNS. The size of the HAuNS was determined using dynamic light scattering on a Brookhaven 90 plus particle size analyzer (Holtsville, NY). Ultraviolet-visible spectroscopy was recorded on a Beckman Coulter DU800 ultraviolet-visible spectrometer (Fullerton, CA). The morphology of the HAuNS was examined using a JEM 1010 transmission electron microscope (JEOL USA, Inc., Peabody, MA). For the preparation of PEG-HAuNS, briefly, $2 \mathrm{~mL}$ of HAuNS (100 optical density [OD]) were added to argon-purged aqueous solution containing PEG sulfhydryl $(3 \mu \mathrm{mol})$. The reaction was allowed to proceed overnight at room temperature. For purification, the reaction mixture was centrifuged at $10,000 \mathrm{rpm}$ for $15 \mathrm{~min}$, and the resulting pellet was resuspended in deionized water. The process was repeated twice to remove any unattached PEG molecules. 


\section{${ }^{64} \mathrm{Cu}$ radiolabeling of PEG-HAuNS}

For conjugation of the radiometal chelator to PEGHAuNS, 1,4,7,10-tetraazacyclododecane - $N, N^{\prime}, N^{\prime \prime}, N^{\prime \prime \prime}-$ tetraacetic acid thioctamide (DOTA-TA, $1.0 \mathrm{mg} / \mathrm{mL}$; $20 \mu \mathrm{L}$ ) was mixed with $1.0 \mathrm{~mL}$ of aqueous solution of HAuNS $(160 \mathrm{OD} / \mathrm{mL})$ for $6 \mathrm{~h}$ at room temperature. Unreacted DOTA-TA was removed by centrifugation at 10,000 rpm for $10 \mathrm{~min}$. Then DOTA-conjugated HAuNS was further reacted with PEG sulfhydryl to obtain DOTA-conjugated PEG-HAuNS. Conjugating PEG to HAuNS first followed by introduction of DOTA was proven to be less efficient perhaps because the steric barrier formed by PEG chains could prevent DOTA-TA from approaching the surface of HAuNS. For radiolabeling with ${ }^{64} \mathrm{Cu}$, aliquots of DOTA-conjugated PEGHAuNS $(160 \mathrm{OD} / \mathrm{mL})$ in $0.1-\mathrm{M}$ sodium acetate solution $(\mathrm{pH}$ 5.4) were mixed with an aqueous solution of ${ }^{64} \mathrm{CuCl}_{2}(10 \mathrm{mCi})$ for $1 \mathrm{~h}$. The radiolabeled nanoparticles were then purified by centrifugation at 10,000 rpm for $10 \mathrm{~min}$ and washed 3 times with phosphate-buffered saline. The nanoparticles were resuspended in phosphatebuffered saline. The radiolabeling efficiency and the stability of labeled nanoparticles were analyzed using instant thin-layer chromatography. The paper strips were developed with phosphate-buffered saline ( $\mathrm{pH}$ 7.4) containing $4.0 \mathrm{mM}$ ethylenediaminetetraacetic acid, and the radioactivity was quantified using a Bioscan IAR-2000 thin-layer chromatography imaging scanner (Washington, DC). Free ${ }^{64} \mathrm{Cu}^{2+}$ moved to the solvent front ( $\left.\mathrm{Rf}=0.9-1.0\right)$, and the nanoparticles remained at the original spot $(R f=0.0)$. The labeling efficiency was $>95 \%$.

\section{Transmission electron microscopy (TEM)}

The tissue uptake of PEG-HAuNS was studied by TEM. Briefly, sections of liver tissue from a control mouse and a male mouse at 14-day time point were fixed with a solution containing $3 \%$ glutaraldehyde plus $2 \%$ paraformaldehyde in $1.0 \mathrm{M}$ cacodylate buffer $(\mathrm{pH} 7.3)$ for $1 \mathrm{~h}$. After fixation, the samples were washed and treated with $0.1 \%$ Millipore-filtered (Billerica, MA), cacodylatebuffered tannic acid, post-fixed with $1 \%$ buffered osmium tetroxide for $30 \mathrm{~min}$, and stained en bloc with 1\% Millipore-filtered uranyl acetate. The samples were dehydrated in increasing concentrations of ethanol, infiltrated, and embedded in Ladd- 112 medium. The samples were polymerized in an oven at $70^{\circ} \mathrm{C}$ for 2 days. Ultrathin sections were cut in a Leica Ultracut microtome (Deerfield, IL), stained with uranyl acetate and lead citrate in a Leica EM stainer, and examined in a JEM 1010 transmission electron microscope (JEOL USA, Inc.) at an accelerating voltage of $80 \mathrm{KV}$. Digital images were obtained using the AMT Imaging System (Advanced Microscopy Techniques Corp, Danvers, MA).

\section{Cytotoxicity}

Cytotoxicity was measured using the MTT assay according to the manufacturer's suggested procedures. LLCPK1 and HepG2 cells were exposed to PEG-HAuNS at various concentrations for 4,24 , and $48 \mathrm{~h}$. The data are expressed as percentage of survival cells and are reported as the means of triplicate measurements in a single experiment.

\section{Complement activation}

Platelet-poor plasma was prepared by centrifugation of freshly drawn whole human blood for $10 \mathrm{~min}$ at 2,500 $\mathrm{g}$ and was used fresh. Complement activation experiments were performed as described previously (http://ncl.cancer.gov/NCL_Method_ITA-5.pdf). Briefly, equal volumes $(10 \mu \mathrm{L})$ of test samples (PEG-HAuNS at final concentration of $1 \mathrm{mg} / \mathrm{mL}$, cobra venom factor at concentration of $50 \mathrm{U}$ as positive control, or PBS as negative control), freshly prepared plasma, and veronal-buffer were mixed together and incubated at $37^{\circ} \mathrm{C}$ for $60 \mathrm{~min}$. The reaction was stopped by the addition of $4 \times$ NuPAGE sample buffer (Invitrogen, Carlsbad, CA). After heating for $5 \mathrm{~min}$ at $90^{\circ} \mathrm{C}, 30 \mu \mathrm{L}$ of the sample were resolved on $10 \%$ Trisglycine gel. For Western blot analysis, proteins separated by 2dimensional polyacrylamide gel electrophoresis were transferred onto a Westran S nylon (Whatman Inc., Florham Park, NJ) membrane and probed with goat polyclonal antibodies specific to $\mathrm{C} 3$ component of complement (Calbiochem, San Diego, CA).

\section{Platelet aggregation}

To study the nanoparticles' effects on platelet aggregation, whole human blood was centrifuged $8 \mathrm{~min}$ at $200 \mathrm{~g}$ to obtain platelet-rich plasma, which was then treated with PEG-HAuNS $(0.008,0.04,0.2$, and $1.0 \mathrm{mg} / \mathrm{mL})$ or collagen (positive control; Helena Laboratories, Beaumont, TX) for $15 \mathrm{~min}$ at $37^{\circ} \mathrm{C}$. To investigate whether PEG-HAuNS can interfere with collagen-induced platelet aggregation, platelet-rich plasma was also treated with the mixture of collagen and PEG-HAuNS under the same conditions. A single-platelet count was then conducted using a Z2 counter and size analyzer (Beckman Coulter, Inc.). A decrease in the single-platelet count occurring due to the platelet aggregation was used to calculate percentage aggregation. A detailed protocol is available at http://ncl.cancer.gov/NCL Method ITA-2.pdf.

\section{Pharmacokinetics and biodistribution}

All animal studies were carried out at MD Anderson Cancer Center (MDACC) under Institutional Animal Care and Use Committee-approved protocols. All animal cages were sanitized on a regular schedule. No known contaminants were present in the bedding which could interfere and affect the results of the study. Diet was a 
commercial, dry rodent chow provided ad libitum. Water source was the public supply given ad libitum. Mice were killed by $\mathrm{CO}_{2}$ exposure at the end of the each study.

For the pharmacokinetic study, 8 healthy female Swiss mice (22-25 g; Charles River Laboratories, Wilmington, MA) were each injected intravenously with $0.125 \mathrm{~mL}$ of ${ }^{64} \mathrm{Cu}$-labeled PEG-HAuNS (activity: $20 \mu \mathrm{Ci} ; 6.25 \mathrm{mg} / \mathrm{kg}$ of 50 OD PEG-HAuNS). At predetermined intervals ( 0 to $\sim 24 \mathrm{~h}$ ), blood samples $(10 \mu \mathrm{L})$ were taken from the tail vein, and the radioactivity of each sample was measured with a gamma counter (Packard, Downers Grove, IL). The percentage of the injected dose per gram of blood (\%ID/g) was calculated. The blood pharmacokinetic parameters for the radiotracer were analyzed using a noncompartmental model with WinNonlin 5.0.1 software (Pharsight, Palo Alto, CA).

For the biodistribution study, human ovarian cancer tumors were generated by subcutaneous injection of Hey cells $\left(5.0 \times 10^{6}\right.$ cells/mouse, $\left.\mathrm{n}=6\right)$ in female nu/nu nude mice (Charles River Laboratories). When the average tumor size reached $6-8 \mathrm{~mm}$ in average diameter, the mice were injected subcutaneously with $0.125 \mathrm{~mL}{ }^{64} \mathrm{Cu}$-labeled PEG-HAuNS (activity: $20 \mu \mathrm{Ci} ; 6.25 \mathrm{mg} / \mathrm{kg}$ of $50 \mathrm{OD}$ PEG-HAuNS). The mice were killed at $24 \mathrm{~h}$ after injection. Various tissues, including tumors, were collected and weighed. The radioactivity of each sample was measured with a Cobra gamma counter (Packard Instruments, Downers Grove, IL). Uptake of nanoparticles in various tissues was calculated as \%ID/g.

\section{Antitumor activity}

The antitumor activity of PEG-HAuNS at different doses was investigated in female nude mice (Charles River Laboratories) bearing human ovarian tumors. The tumors were generated by subcutaneous injection of Hey cells $\left(5 \times 10^{6}\right.$ cells/mouse). The diameter of tumors was measured by a vernier caliper, and the tumor volume was calculated according to the following equation: volume $=($ tumor length $) \times(\text { tumor width })^{2} / 2$. When the tumor volume reached $\sim 300 \mathrm{~mm}^{3}$, the mice were divided into 4 groups consisting of 7 or 8 mice/group. Mice in groups 1 to 3 were injected intravenously with a single dose of PEG-HAuNS $(5 \mathrm{~mL} / \mathrm{kg}$ of 25,50 , or 100 OD nanoparticles, corresponding to $3.13 \mathrm{mg} / \mathrm{kg}, 6.25 \mathrm{mg} / \mathrm{kg}$, or $13.5 \mathrm{mg} / \mathrm{kg}$, respectively). The mice in group 4 , as controls, were injected intravenously with a single dose of saline $(5 \mathrm{~mL} / \mathrm{kg})$. Tumors in all of the groups were irradiated with an NIR laser $\left(2.5 \mathrm{~W} / \mathrm{cm}^{2}\right.$ for $\left.3 \mathrm{~min}\right)$ at $24 \mathrm{~h}$ after drug injection. The tumors were measured as described before. At the end of the experiment (tumors reached $>1,500 \mathrm{~mm}^{3}$ or 10 days after initial injection, whichever came first), the mice were killed and the tumors removed and weighed.
Human ovarian A2780 tumors were generated by subcutaneous injection of the cells $\left(8.0 \times 10^{6}\right.$ cells/mouse). When tumor volume reached $\sim 500 \mathrm{~mm}^{3}$, mice were divided into two groups. Mice in group $1(n=6)$ were injected intravenously with saline $(5.0 \mathrm{~mL} / \mathrm{kg})$ and mice in group $2(\mathrm{n}=7)$ were injected with PEG-HAuNS $(5.0 \mathrm{~mL} / \mathrm{kg}$ of $50 \mathrm{OD} ; 6.25 \mathrm{mg} / \mathrm{kg})$. Mice in both groups were irradiated with NIR laser (Diomed 15 plus, UK) above the skin surface at $24 \mathrm{~h}$ after injection at a power density of $2.5 \mathrm{~W} / \mathrm{cm}^{2}$ for $3 \mathrm{~min}$ ). The tumor dimensions were measured with a caliper, and the tumor volume was calculated according to the equation: Volume = (Tumor Length) $\times(\text { Tumor Width })^{2} / 2$. At the end of the experiment (tumors reached $>2000 \mathrm{~mm}^{3}$ or 22 days after initial injection, whichever came first), mice were killed by $\mathrm{CO}_{2}$ overexposure and tumors were removed and weighed.

\section{Acute and chronic toxicity}

A total of 24 male and 24 female 8 weeks CD1 mice (Charles River Laboratories) were assigned to 4 groups (6 mice/sex/group). Two groups were injected intravenously with PEG-HAuNS (treated) at a dose of $12.5 \mathrm{mg} / \mathrm{kg}$ (accumulated dose: $125 \mathrm{mg} / \mathrm{kg}$ ) and 2 were injected with saline (controls), for a total of 10 injections, administered daily for 5 injections per week over a 2 -week period. At 14 and 90 days from the first injection, 12 mice ( 6 male, 6 female) were killed. The following tissues were collected at necropsy for histological examination: liver, gall bladder, kidneys, lungs, spleen, skeletal muscle, heart, aorta, adrenal glands, brain, eyes, lacrimal glands, pituitary gland, sciatic nerve, spinal cord, pancreas, stomach, duodenum, jejunum, ileum, cecum, colon, rectum, mesenteric lymph node, salivary glands, mandibular lymph node, thymus, larynx/pharynx with tongue, thyroid gland, parathyroid glands, trachea, esophagus, skin, mammary glands (females only), urinary bladder, female reproductive organs (ovaries, uterus, cervix), male reproductive organs (testes, epididymis, prostate, seminal vessicles), femur with knee joint, sternum, sternal bone marrow, and injection site (tail vein). At the time of necropsy, cardiac blood was collected for hematologic and clinical chemistry analysis, and any gross observations were noted. Selected organs were weighed at the time of necropsy (liver, spleen, kidneys), and relative organ weights were calculated on the basis of the terminal body weights. All tissues were fixed in $10 \%$ neutral buffered formalin, processed into paraffin-embedded blocks, and cut into 5-micron sections for histologic examination by a board-certified veterinary pathologist.

To investigate the elimination of PEG-HAuNS in mice, the Au content of liver, spleen, kidney, and muscle samples of 6 CD1 mice (3 male, 3 female) killed at day 14 and day 90 was measured using neutron activation analysis at 
the University of Missouri Research Reactor Facility (Columbia, MO). Tissue samples were prepared by weighing the as-received samples into precleaned, high-density polyethylene irradiation vials and lyophilizing the tissue to constant dry weight. The samples were then loaded in polyethylene transfer "rabbits" in sets of nine and were irradiated for $90 \mathrm{~s}$ in a thermal flux density of approximately $5 \times 10^{13} \mathrm{n} \mathrm{cm}^{-2} \mathrm{~s}^{-1}$. The samples were then allowed to decay for 24 to $48 \mathrm{~h}$ and counted in real time on a high-purity germanium detector for $3600 \mathrm{~s}$ at a sample-to-detector distance of approximately $5 \mathrm{~cm}$. The mass of gold in a sample was quantified by measuring the $411.8 \mathrm{KeV}$ gamma ray from the $\beta^{-}$decay of ${ }^{198} \mathrm{Au} \quad\left(\mathrm{t}_{1 / 2}=2.7\right.$ days $)$. Six geometrically equivalent comparator standards, prepared by pipetting approximately $0.1(\mathrm{n}=3)$ and $0.01(\mathrm{n}=3) \mathrm{mg}$ of gold from a $(10.0 \pm 0.5) \mu \mathrm{g} / \mathrm{mL}$ certified standard solution (HighPurity Standards) on paper pulp in the polyethylene irradiation vials, were used with each sample set.

\section{Statistics}

Mean differences in tumor size at the $10^{\text {th }}$ day of treatment between the 4 treatment groups of mice with Hey tumors were analyzed by analysis of variance, with $p<$ 0.05 considered to be statistically significant. Difference on tissue concentration between day-14 and day- 90 after the first injection was analyzed using student's $t$-test (paired, two-tail test).

\section{Additional file}

Additional file 1: Table S1. Group means for terminal body weights (TBW) for both the 14-day and 90-day sacrifices and the calculated percent of control for each sacrifice date. Table S2. Group means of organ weight relative to body weight and percent of control for both sacrifice dates and sexes. Table S3. Group means for both sacrifice dates and both sexes for hematology. Table S4. Summary of incidences and average group grades for all microscopic observations. Figure S1. Cell viability as a function of PEG-HAuNS concentration. LLC-PK1 (A) and HepG2 (B) cells were treated with PEG-HAuNS for 4, 24, and $48 \mathrm{hr}$. The viability of cells was determined using the MTT assay. Figure S2. Antitumor activity of PEG-HAuNS against A2780 tumor in nude mice. A: A2780 tumor growth curves in mice treated with saline $(n=6)$ and with PEG-HAuNS $(n=7)$. All tumors in both groups received NIR laser illumination from the tumor's surface $\left(2.5 \mathrm{~W} / \mathrm{cm}^{2}\right.$, for 3 $\mathrm{min}$ ) at $24 \mathrm{~h}$ after intravenous injection of PEG-HAuNS (single, $6.25 \mathrm{mg} / \mathrm{kg}$ ). B: Average tumor weight in saline- and PEG-HAuNS-treated groups on day 21 after NIR laser illumination. Figure S3. Spleen with pigment. The 14-day pigment deposition is much greater than what is observed at 90 days. At 14 days, the pigment deposits were smaller and distributed diffusely throughout the spleen. At 90 days, the deposits were larger and fewer, and focal and random throughout the spleen. Magnification, $\times 400$.

\section{Competing interest}

The authors have no potential competing interest to disclose.

\section{Authors' contributions}

JY carried out all studies and drafted the manuscript. JZ participated in data analysis and manuscript preparation. MZ participated in biodistribution study. $Y L$ participated in the synthesis of PEG-HAuNS. JDR carried out quantitative analysis of tissue concentration of $\mathrm{Au}$. DL carried out pharmacokinetic analysis.
CVP designed in vivo toxicity study, carried out tissue histopathological analysis, and drafted the manuscript. $C L$ designed the work and drafted the manuscript. All authors read and approved the final manuscript.

\section{Acknowledgment}

We thank Luanne Jorewicz for editing the article. The blood compatibility assays (complement activation and platelet aggregation) were performed at Nanotechnology Characterization Lab (NCL), National Cancer Institute. This work was supported in part by the National Cancer Institute (U54CA151668), the John S. Dunn Foundation and the National Nature Science Foundation of China (81373348 and 81001411). SEM and TEM studies were performed at the High Resolution Transmission Electron Microscopy Core of MD Anderson Cancer Center.

\section{Author details}

${ }^{1}$ College of Pharmaceutical Sciences, Zhejiang University, Yuhangtang Road 388, Hangzhou 310058, People's Republic of China. ²Department of Cancer Systems Imaging, Unit 59, The University of Texas MD Anderson Cancer Center, Houston, TX 77030, USA. ${ }^{3}$ Department of Chemistry, University of Missouri-Columbia, Columbia, MO 65211, USA. ${ }^{4}$ Department of Pharmaceutical Sciences, College of Pharmacy and Health Sciences, Texas Southern University, 3100 Cleburne Street, Houston, TX 77004, USA.

${ }^{5}$ Department of Veterinary Medicine and Surgery, The University of Texas MD Anderson Cancer Center, Houston 77030, TX, USA.

Received: 27 December 2013 Accepted: 3 May 2014

Published: 30 May 2014

\section{References}

1. Caruthers SD, Wickline SA, Lanza GM: Nanotechnological applications in medicine. Curr Opin Biotechnol 2007, 18:26-30.

2. Li C: A targeted approach to cancer imaging and therapy. Nat Mater 2014, 13:110-115.

3. Guzman KAD, Taylor MR, Banfield JF: Environmental risks of nanotechnology: national nanotechnology initiative funding, 2000-2004. Environ Sci Technol 2006, 40:1401-1407.

4. Borm PJA, Muller-Schulte D: Nanoparticles in drug delivery and environmental exposure: same size, same risks? Nanomedicine 2006, 1:235-249.

5. Carrero-Sanchez JC, Elias AL, Mancilla R, Arrellin G, Terrones H, Laclette JP, Terrones M: Biocompatibility and toxicological studies of carbon nanotubes doped with nitrogen. Nano Lett 2006, 6:1609-1616.

6. Fiorito S, Serafino A, Andreola F, Togna A, Togna G: Toxicity and biocompatibility of carbon nanoparticles. J Nanosci Nanotechnol 2006, 6:591-599.

7. Federici G, Shaw BJ, Handy RD: Toxicity of titanium dioxide nanoparticles to rainbow trout (oncorhynchus mykiss): gill injury, oxidative stress, and other physiological effects. Aquat Toxicol 2007, 84:415-430.

8. Chen J, Dong X, Zhao J, Tang G: In vivo acute toxicity of titanium dioxide nanoparticles to mice after intraperitioneal injection. J App/ Toxicol 2009, 29:330-337.

9. Gurr JR, Wang ASS, Chen CH, Jan KY: Ultrafine titanium dioxide particles in the absence of photoactivation can induce oxidative damage to human bronchial epithelial cells. Toxicology 2005, 213:66-73.

10. Pissuwan D, Valenzuela SM, Cortie MB: Therapeutic possibilities of plasmonically heated gold nanoparticles. Trends Biotechnol 2006, 24:62-67.

11. Qian X, Peng XH, Ansari DO, Yin-Goen Q, Chen GZ, Shin DM, Yang L, Young AN, Wang MD, Nie S: In vivo tumor targeting and spectroscopic detection with surface-enhanced Raman nanoparticle tags. Nat Biotechnol 2008, 26:83-90.

12. Costi R, Saunders AE, Elmalem E, Salant A, Banin U: Visible light-induced charge retention and photocatalysis with hybrid CdSe-Au nanodumbbells. Nano Lett 2008, 8:637-641.

13. Kerman K, Kraatz HB: Electrochemical detection of kinase-catalyzed thiophosphorylation using gold nanoparticles. Chem Commun 2007, 21:5019-5021.

14. Poon L, Zandberg W, Hsiao D, Erno Z, Sen D, Gates BD, Branda NR: Photothermal release of single-stranded DNA from the surface of gold nanoparticles through controlled denaturating and Au-S bond breaking. ACS Nano 2010, 4:6395-6403. 
15. Nusz GJ, Curry AC, Marinakos SM, Wax A, Chilkoti A: Rational selection of gold nanorod geometry for label-free plasmonic biosensors. ACS Nano 2009, 3:795-806.

16. Ghosh PS, Kim CK, Han G, Forbes NS, Rotello VM: Efficient gene delivery vectors by tuning the surface charge density of amino acid-functionalized gold nanoparticles. ACS Nano 2008, 2:2213-2218.

17. Brown SD, Nativo P, Smith JA, Stirling D, Edwards PR, Venugopal B, Flint DJ Plumb JA, Graham D, Wheate NJ: Gold nanoparticles for the improved anticancer drug delivery of the active component of oxaliplatin. J Am Chem Soc 2010, 132:4678-4684.

18. Elbakry A, Zaky A, Liebkl R, Rachel R, Goepferich A, Breunig M: Layer-by-layer assembled gold nanoparticles for siRNA delivery. Nano Lett 2009, 9:2059-2064.

19. Merchant B: Gold, the noble metal and the paradoxes of its toxicology. Biologicals 1998, 26:49-59.

20. Connor EE, Mwamuka J, Gole A, Murphy CJ, Wyatt MD: Gold nanoparticles are taken up by human cells but do not cause acute cytotoxicity. Small 2005, 1:325-327.

21. Shukla R, Bansal V, Chaudhary M, Basu A, Bhonde RR, Sastry M: Biocompatibility of gold nanoparticles and their endocytotic fate inside the cellular compartment: a microscopic overview. Langmuir 2005, 21:10644-10654

22. Goodman CM, McCusker CD, Yilmaz T, Rotello VM: Toxicity of gold nanoparticles functionalized with cationic and anionic side chains. Bioconjugate Chem 2004, 15:897-900.

23. Pernodet N, Fang XH, Sun Y, Bakhtina A, Ramakrishnan A, Sokolov J, Ulman A, Rafailovich M: Adverse effects of citrate/gold nanoparticles on human dermal fibroblasts. Small 2006, 2:766-773.

24. Chithrani BD, Chan WC: Elucidating the mechanism of cellular uptake and removal of protein-coated gold nanoparticles of different sizes and shapes. Nano Lett 2007, 7:1542-1550.

25. Pan Y, Neuss S, Leifert A, Fischler M, Wen F, Simon U, Schmid G, Brandau W, Jahnen-Dechent W: Size-dependent cytotoxicity of gold nanoparticles. Small 2007, 3:1941-1949.

26. Alkilany AM, Murphy CJ: Toxicity and cellular uptake of gold nanoparticles: what we have learned so far? J Nanopart Res 2010, 12:2313-2333

27. Lee $\mathrm{S}$, Chon H, Lee M, Choo J, Shin SY, Lee YH, Rhyu IJ, Son SW, Oh CH: Surface-enhanced Raman scattering imaging of HER2 cancer markers overexpressed in single MCF7 cells using antibody conjugated hollow gold nanospheres. Biosens Bioelectron 2009, 24:2260-2263.

28. Lu W, Huang Q, Geng KB, Wen XX, Zhou M, Guzatov D, Brecht P, Su R, Oraevsky A, Wang LV, Li C: Photoacoustic imaging of living mouse brain vasculature using hollow gold nanospheres. Biomaterials 2010, 31:2617-2626.

29. Melancon MP, Lu W, Yang Z, Zhang R, Cheng Z, Elliot AM, Stafford J, Olson T, Zhang JZ, Li C: In vitro and in vivo targeting of hollow gold nanoshells directed at epidermal growth factor receptor for photothermal ablation therapy. Mol Cancer Ther 2008, 7:1730-1739.

30. Melancon MP, Zhou M, Li C: Cancer theranostics with near-infrared light-activatable multimodal nanoparticles. Acc Chem Res 2011, 44:947-956.

31. Kumar R, Maitra AN, Patanjali PK, Sharma P: Hollow gold nanoparticles encapsulating horseradish peroxidase. Biomaterials 2005, 26:6743-6753.

32. Lu W, Zhang G, Zhang R, Flores LG 2nd, Huang Q, Gelovani JG, Li C: Tumor site-specific silencing of NF-kappaB p65 by targeted hollow gold nanosphere-mediated photothermal transfection. Cancer Res 2010, 70:3177-3188

33. You J, Shao R, Wei X, Gupta S, Li C: Near-infrared light triggers release of paclitaxel from biodegradable microspheres: photothermal effect and enhanced antitumor activity. Small 2010, 6:1022-1031.

34. You J, Zhang G, Li C: Exceptionally high payload of doxorubicin in hollow gold nanospheres for near-infrared light-triggered drug release. ACS Nano 2010, 4:1033-1041.

35. Wu G, Mikhailovsky A, Khant HA, Fu C, Chiu W, Zasadzinski JA: Remotely triggered liposome release by near-infrared light absorption via hollow gold nanoshells. J Am Chem Soc 2008, 130:8175-8177.

36. Patra HK, Banerjee S, Chaudhuri U, Lahiri P, Dasgupta AK: Cell selective response to gold nanoparticles. Nanomedicine 2007, 3:111-119.

37. Lankveld DP, Rayavarapu RG, Krystek P, Oomen AG, Verharen HW, van Leeuwen TG, De Jong WH, Manohar S: Blood clearance and tissue distribution of PEGylated and non-PEGylated gold nanorods after intravenous administration in rats. Nanomedicine (Lond) 2011, 6:339-349.

38. Akiyama Y, Mori T, Katayama Y, Niidome T: The effects of PEG grafting level and injection dose on gold nanorod biodistribution in the tumor-bearing mice. J Control Release 2009, 139:81-84

39. Niidome T, Yamagata M, Okamoto Y, Akiyama Y, Takahashi H, Kawano T, Katayama Y, Niidome Y: PEG-modified gold nanorods with a stealth character for in vivo applications. J Control Release 2006, 114:343-347.

40. Zhang G, Yang Z, Lu W, Zhang R, Huang Q, Tian M, Li L, Liang D, Li C: Influence of anchoring ligands and particle size on the colloidal stability and in vivo biodistribution of polyethylene glycol-coated gold nanoparticles in tumor-xenografted mice. Biomaterials 2009, 30:1928-1936.

41. Elwell M, Mahler J: Heart, blood vessels, and lymphatics. In Pathology of the Mouse Reference and Atlas. Edited by Maronpot R. Vienna, IL: Cache River Press; 1999:361-380.

doi:10.1186/1743-8977-11-26

Cite this article as: You et al:: Pharmacokinetics, clearance, and biosafety of polyethylene glycol-coated hollow gold nanospheres. Particle and Fibre Toxicology 2014 11:26.

\section{Submit your next manuscript to BioMed Central and take full advantage of:}

- Convenient online submission

- Thorough peer review

- No space constraints or color figure charges

- Immediate publication on acceptance

- Inclusion in PubMed, CAS, Scopus and Google Scholar

- Research which is freely available for redistribution 